as being in conflict with upholding the principle of individual autonomy ${ }^{3}$ and selfselected applicants are denied testing. We suggest that this has a number of important repercussions. It may be that a testing protocol which incorporates a selection ethos encourages people to "fake good", evidence of this being suggested by scores on the validity scales of psychometric tests administered as part of the pretest protocol. ${ }^{4}$ We suggest that placing at risk subjects in what they may perceive to be a highly evaluative situation lays considerable burden on them. Indeed, one couple that we have seen recently reported experiencing conflict and apportioning of blame ("Which of us was unable to cope with the test result?") after perceiving themselves as having been denied a test result.

We have felt it important to consider the implications of this selection role for our service and clients. Our major concern is that the concept of selection will militate against the open relationship necessary to carry out the client focused aim of pretest counselling, which is facilitating insight and understanding that will help people in their decision making process concerning predictive testing and subsequent adjustment to the result. We cannot expect people to be open and reflective with counsellors whom they see as having the power to judge whether they should be given a result that they are highly motivated to receive. Those considering predictive testing are bound to experience ambivalent feelings as regards their motives for testing and the impact of a result on their lives. We feel that it is important that test applicants be given an opportunity to explore their vulnerabilities and prepare for potential difficulties in dealing with an adverse result and that introducing selection to the pretest counselling agenda will undermine this process.

The ethical principle of "do no harm" is the one frequently quoted in this debate and guidelines for predictive testing protocols have drawn attention to the potentially harmful effects of testing under certain circumstances, notably where the person is seriously depressed or psychologically ill. ${ }^{3}$ Less concern, however, has been voiced with regard to the potential harm in refusing or delaying testing, or attempting to carry out the aims of pretest counselling with the agenda of selection ever present. The question of how applicants (and their partners) cope with being told that they are not ready to receive a test result has not been given any attention.

In consideration of this dilemma in our own centre, we have not abandoned exclusion criteria completely but have tried to separate the gatekeeping/selection role from the continuing counselling. We attempt to make this distinction explicit to those going through testing, subsequent to the preliminary clinic appointment. The gatekeeping role is restricted to the preliminary consultation and thereafter the decision about receiving a test result is exclusively the client's. While this seems to work in promoting exploration and reflection of difficult thoughts and feelings by the person, it does not always sit comfortably with ourselves. Observers of our team meetings frequently witness our struggling with uncertainty, risk, and the fear of possibly adverse outcomes of predictive testing. We are often tempted to return to the security of rigid criteria by enforcing guidelines. On reflection, this experience may provide insight into and empathy with the people that we see in our clinic. We have to remind ourselves that the "special agony of this situation is that none of the possibilities are harmless". ${ }^{2}$ In having to learn to tolerate our own uncertainties, we are learning how to sit with clients while they live with theirs.

JULIA BINEDELL JOANNA R SOLDAN PETER S HARPER Institute of Medical Genetics, University of Wales Collge of Medicine, Collge of Medicine,
Heath Park, Cardiff CF4 $4 X N$, UK

1 Quaid KA. Presymptomatic testing for Huntington disease in the United States. Am $\mathcal{F}$ Hum Genet 1993;53:785-7.

2 Sharpe NF. Presymptomatic testing for Huntington disease: is there duty to test those under the age of eighteen years? $A m \mathcal{F} M e d$ under the age of eight

3 Brandt J. Ethical considerations in genetic testing: an empirical study of presymptomatic diagnosis of Huntington's disease. In: Fulford KWM, Gillett GR, Martin Soskice J, eds. Medicine and moral reasoning. Cambridge: Medicine and moral reasoning. Cambridge:

4 Decruyenaere M, Evers-Kiebooms G, Boogaerts $\mathrm{A}$, et al. Predictive testing for Huntington's disease: risk perception, reasons for testing and psychological profile of test applicants. Genet Couns 1995;6:1-13.

\section{Apolipoprotein E genotype does not affect age at onset in patients with chromosome 14 encoded Alzheimer's disease}

At least four genes are responsible for autosomal dominant early onset Alzheimer's disease $(\mathrm{AD})$ : the $\beta$-amyloid precursor protein (APP) gene on chromosome $21,{ }^{1}$ the genes coding for the putative integral membrane proteins, presenilin 1 and 2 , located respectively on chromosomes 14 and $1,{ }^{23}$ and an as yet unmapped fourth locus. The chromosome 14 gene accounts for the majority of early onset cases with autosomal dominant inheritance. ${ }^{2}$ Besides these dominantly inherited genes, the $\varepsilon 4$ allele of apolipoprotein $\mathrm{E}$ (ApoE) is associated with late as well as with early onset $\mathrm{AD}^{4-7}$ The ApoE $\varepsilon 4$ allele is, therefore, thought to constitute a major risk factor for this disorder, raising the question of a possible interaction between ApoE and the genes responsible for autosomal dominant $\mathrm{AD}$. The ApoE genotype can influence the age at onset in AD patients with APP mutations, ${ }^{89}$ but no such effect was observed in a series of families with chromosome 14 encoded $\mathrm{AD} .{ }^{10} \mathrm{In}$ order to confirm the latter result in an independant series, we evaluated the effect of ApoE genotype on the age at onset in three large pedigrees with early onset $\mathrm{AD}$ in which linkage to the $\mathrm{AD} 3$ locus on chromosome 14 was established.

Fifteen consenting patients from three families with early onset $\mathrm{AD}$ were evaluated using a standardised procedure in order accurately to determine their age at onset and their clinical profile. ApoE genotypes were identified from blood DNA, as previously described. ${ }^{11}$ Linkage to the $\mathrm{AD} 3$ locus has already been reported for two pedigrees (FAD-RO1 and FAD-ROU-011) ${ }^{12}$ (Bellis et al, submitted). Linkage analysis in family FAD-SAL-511, which included six affected members, generated a peak lod score of 1.81 at $\theta=0.00$ for marker D14S268 located $1 \mathrm{cM}$ centromeric to D14S77, suggestive of linkage to the $\mathrm{AD} 3$ locus. Furthermore, three heterozygous missense mutations in the presenilin 1 gene, Leu392Val, Pro264Leu, and Cys410Tyr, were found, respectively, in patients from families FAD-RO1, FADROU-011, and FAD-SAL-511. ${ }^{13}$ Means were compared using the Mann-Whitney U test.

Age at onset and ApoE genotypes are shown in the table. Mean age at onset was not significantly affected by family membership or genotype. The $\varepsilon 3 \varepsilon 4$ genotype was associated with the earliest onset in family FAD-RO1, but also with the latest in the same family, and in kindred FAD-SAL-005. These results clearly confirm that the ApoE genotype does not modulate age at onset in patients with AD3 gene mutations. This might reflect the absence of an interaction between presenilin 1 and ApoE. However, the mechanism by which heterozygous mutations in the presinilin 1 gene causes $\mathrm{AD}$ is still unknown. The effect of ApoE genotype on the age at onset in patients with the APP717 Val $\rightarrow$ Ile mutation might, on the contrary, reflect the high affinity binding of ApoE allele $\varepsilon 4$ to the $\beta$-A4 peptide which results from APP cleavage. $^{5}$

We thank Drs Pascale Benlian for technical advice and Merle Ruberg for helpful discussion. This work was supported by the Association France Alzheimer, INSERM (Clinical Network 492002) and Caisse Nationale de l'Assurance Maladie des Travailleurs Salariés (998558)

THE FRENCH ALZHEIMER'S DISEASE COLLABORATIVE STUDY GROUP

French Alzheimer's Disease Collaborative Study Group: $A$ Brice, $S$ Tardieu, $O$ Didierjean, E LeGuern, A Michon, B Pillon, V Hahn, $B$ Dubois, $C$ Penet, Y Agid, INSERM U289, Hôpital de la Salpêtrière, Paris; $D$ Campion, $M$ Martinez, M-C Babron, F Clerget-Darpoux M Martinez, M-C Babron, F Clerget-Darpoux, INSERM U155, Château de Longchamp, Paris;
$M$ Bellis, A Calanda, CNRS UPR 8402-INSERM U249, Montpellier; $R$ Heilig, $\mathcal{J}$ Weissenbach,
Und Généthon, Evry; $\mathcal{f}$ Mallet, CNRS, Gif-sur-Yvette $T$ Frébourg, D Hannequin, Hôpital Charles Nicolle, Rouen; $M$ Puel, CHU Purpan, Toulouse; $F$ Ledoze, CHU, Caen; F Pasquier, Hôpital B, Lille, M-A Zimmermann, Hôpital Civil, Strasbourg C Thomas-Anterion, Hôpital Bellevue, Saint-Etienne, O Moreau, $\mathrm{CHU}$, Grenoble, France.

Correspondence to:
Dr A Brice,
INSERM U289,
Hôpital de la Salpêtrière,
47 Bd de l'Hópital,
75651 Paris Cedex 13,
France.

1 Goate A, Chartier-Harlin MC, Mullan M, et al. Segregation of a missense mutation in the

Age at onset of $A D$ according to families and ApoE genotypes

\begin{tabular}{|c|c|c|c|c|}
\hline \multirow[b]{2}{*}{ Family } & \multicolumn{3}{|c|}{ ApoE genotype } & \multirow[b]{2}{*}{$\begin{array}{l}\text { Age at onset } \\
\text { Mean (SD) } \\
\text { (years) }\end{array}$} \\
\hline & $\begin{array}{l}\varepsilon 2 \varepsilon 3 \\
\text { age at onset } \\
\text { (years) }\end{array}$ & $\begin{array}{l}\varepsilon 3 \varepsilon 3 \\
\text { age at onset } \\
\text { (years) }\end{array}$ & $\begin{array}{l}\varepsilon 3 \varepsilon 4 \\
\text { age at onset } \\
\text { (years) }\end{array}$ & \\
\hline $\begin{array}{l}\text { FAD-RO1 } \\
\text { FAD-SAL-511 } \\
\text { FAD-ROU-011 } \\
\text { Age at onset } \\
\text { Mean (SD) (years) }\end{array}$ & $\begin{array}{l}40 \\
40\end{array}$ & $\begin{array}{l}41,44,45,46,48,49 \\
45,54,55 \\
47 \cdot 4(4 \cdot 6)\end{array}$ & $\begin{array}{l}40,49,51 \\
51 \\
60 \\
50 \cdot 2(7 \cdot 1)\end{array}$ & $\begin{array}{lr}45.9 & (3 \cdot 8) \\
51.3 & (4 \cdot 5) \\
50 & (14.1) \\
47.9 & (5 \cdot 8)\end{array}$ \\
\hline
\end{tabular}


amyloid precursor protein gene with familia Alzheimer's disease. Nature 1991;349:704-6.

2 Sherrington R, Rogaev EI, Liang Y, et al. Cloning of a gene bearing missense mutations in ing of a gene bearing missense mutations in early-onset familial A

3 Levy-Lahad E, Wasco W, Pookaj P, et al. Candidate gene for the chromosome 1 familia Alzheimer's disease locus. Science 1995;269. 973-7.

4 Saunders AM, Strittmatter WJ, Schmechel D, et al. Association of apolipoprotein $\mathrm{E}$ allele $\varepsilon 4$ with late-onset familial and sporadic Alzheimer's disease. Neurology 1993;43:1467-72.

5 Strittmatter WJ, Saunders AM, Schmechel D et al. Apolipoprotein E: high avidity binding to beta-amyloid and increased frequency of the type 4 allele in late-onset familial Alzheimer's type 4 allele in late-onset familial Alzheimer's 1977-81.

6 Chartier-Harlin MC, Parfitt M, Legrain S, et al. Apolipoprotein $\mathrm{E}, \mathrm{E} 4$ allele as a major risk Apolipoprotein E, E4 allele as a major ris factor for sporadic early and late-onset form of Alzheimer's disease: analysis of the $19 \mathrm{q} 13.2$ chromosomal region. Hum Mol Genet 1994;3: 569-74.

7 Van Duijn CM, de Knijff P, Cruts $M$, et al. Apolipoprotein E4 allele in a population-based study of early-onset Alzheimer's disease. Nature Genet 1994;7:74-7.

8 Hardy J, Houlden $\mathrm{H}$, Collinge J, et al. Apolipoprotein E genotype and Alzheimer's disease. Lancet 1993;342:737-8.

9 St George-Hyslop P, Crapper McLachlan D Tuda T, et al. Alzheimer's disease and possible gene interaction. Science 1994;263:537.

10 Van Broeckhoven C, Backhovens H, Cruts $M$, et al. APOE genotype does not modulate age at onset in families with chromosome 14 encoded onset in families with chromosome 14 encoded Alzheimer's

11 Hixson JE, Vernier DT. Restriction isotyping of human apolipoprotein $\mathrm{E}$ by gene amplification and cleavage with HhaI. $\mathcal{F}$ Lipid Res 1990;31 545-8.

12 Campion D, Brice A, Hannequin D, et al. A large pedigree with early-onset Alzheimer's disease: clinical, neuropathological, and genetic characterization. Neurology 1995;45:80-5.

13 Campion D, Flaman JM, Brice A, et al. Mutations of the presenilin 1 gene in families with early-onset Alzheimer's disease. Hum Mol Genet 1995;4:2373-7.

\section{BOOK REVIEWS}

If you wish to order or require further information regarding the titles reviewed here, please write to or telephone the BMJ Bookshop, PO Box 295, London WC1H 9JR. Tel 0171383 6244. Fax 0171383 6662. Books are supplied post free in the UK and for BFPO addresses. Overseas customers should add $15 \%$ for postage and packing. Payment can be made by cheque in sterling drawn on a UK bank or by credit card (Mastercard, Visa, or American Express) stating card number, expiry date, and full name. (The price and availability are occasionally subject to revision by the Publishers.)

Gene Therapy: A Handbook for Physicians. K W Culver. (Pp 117.) UK: Mary Ann Liebert Publishers. 1994.

The foreword sets the scene. "The recombinant DNA process patented in 1980 opened stunning possibilities that, in a single decade, brought the concepts of 'inborn errors of metabolism' . . . and 'the double helix' to the bedside of a critically sick little girl. On September 14th, 1990, at 12:52 in the afternoon, Dr Culver inserted a needle into the left hand of that child, started the infusion of genetically repaired cells, and, quite possibly, defined a fundamental change in the human potential for health." The same $\mathrm{Dr}$ Culver is the author of this book, and the event described was the treatment of a child with severe combined immunodeficiency, caused by adenosine deaminase (ADA) deficiency, with $T$ lymphocytes previously removed from the girl's blood, then cultured, transfected with the ADA gene, and reinjected. Clearly, Dr Culver is right at the centre of this gene therapy story and well qualified to write a book on the subject.

But something is wrong. Five years on from that initial injection, no peer reviewed description of the outcome of that work has been published. Sufficient concern has been raised about the scientific rigour of some of the clinical gene therapy trials that early in 1995 Harold Varmus, Director of the US National Institutes of Health, convened two new committees to evaluate both the review process for gene therapy proposals by the Recombinant DNA Advisory Committee (RAC) and the technical state of gene therapy research itself.

It is against this background that one must assess Dr Culver's book. According to the author, it is aimed at physicians who may be asked about gene therapy by their patients but feel ill informed about the subject. Certainly, the work has some attractive features. It is short, succinct, well illustrated, and well referenced. There are a number of useful appendices, for example, Appendix A which lists under "Journals and Periodicals" Human Gene Therapy and Genetic Engineering News, both also published by Mary Ann Liebert Inc (although not, I was surprised to note, Gene Therapy, published by Stockton Press). And in case the reader still feels insufficiently informed about their favourite gene therapy topic, Appendix B lists the telephone numbers of all Principal Investigators who have had protocols approved by the RAC - so why not just call one of them up?

All very cosy, but to me there seems to be a fundamental problem. This is a cookery book of recipes, the end product of which has generally never been made, let alone tasted. Yet by enclosing it in solid red covers, asking the Curator of the National Museum of American History to write the foreword, and spiking it with "historic" photographs from the aforementioned "first gene therapy experiment", a veneer of scientific respectability emerges.

The successful application of gene therapy poses formidable challenges but could bring considerable benefits. Those scientists who have chosen to base their careers on the development of new approaches to gene therapy are brave people and we should salute them. One or two will doubtless become extremely famous (and rich) while the majority labour for years on systems that eventually prove to be of little or no practical use. This book successfully outlines the considerable amount of activity in the field but it is less clear that it will help the physician in the clinic to convey the real state of things to his or her patient.

ANDREW O M WILKIE

Congenital Limb Deficiencies in Hungary. Genetic and Teratologic Epidemiological Studies. A E Czeizel, J A Evans, I Kodaj, W Lenz. (Pp 353; \$54.00.) UK: Akademiai Kiado Publishers. 1995.
This book is subtitled "Genetic and teratologic epidemiological studies" and describes a systematic and exhaustive study of nearly 1000 cases with congenital limb deficiency born in Hungary between 1975 and 1984. Hungary maintains a national computerised record of information about malformed infants and pregnancies terminated, because of prenatally diagnosed developmental defects, during the second and third trimester. Through this database all cases with a limb reduction deformity were ascertained and the diagnosis confirmed by personal examination or evaluation of medical records Hungary has a birth rate of approximately 150000 per year. Notification to the Hungarian Congenital Abnormality Register (HCAR) is the task of obstetricians and paediatricians and because notification is required every time an affected child is admitted to a medical institution, ascertainment is nearly complete.

The first chapter is a fascinating and well illustrated account of the history of limb defects spanning two and a half thousand years, from the clay tablets of Ninevah to the present day. There follows a description of the Hungarian systems for the evaluation of congenital abnormalities. The design of this study of congenital limb deficiency and the subdivision into isolated cases and those with other congenital abnormalities is discussed. The morphological classification which forms the basis for further evaluation is then introduced. Each of the six morphological groups, terminal transverse, amniogenic, radial and tibial, ulnar and fibular, split hand and foot, and proximal intercalary defects, are then evaluated in a systematic manner.

The study's strengths are the enormous volume of data amassed in a population with nearly complete ascertainment, and the painstaking and detailed manner in which the data have been collected and evaluated. The figures for the prevalence of various categories of congenital limb deficiency are a major contribution to the field. Its main weakness lies in the reliance on a morphological classification as the starting point for epidemiological evaluation of aetiology. Study of the range of limb defects that can be observed in different limbs of a single child, and hence presumably with a common aetiology, casts intuitive doubt on the value of this approach. The eventual aetiological classification of isolated CLD groups ends by citing vascular disruption as an important aetiological factor in four of the six categories, with no recognised factors for atypical split hand and foot and early amnion rupture, arguably itself a result of vascular disruption, cited in the sixth (amniogenic) group.

The disappointing message that emerges from this book is that despite a huge and thorough research effort, only a few environmental factors such as smoking emerge as potential aetiological factors. Even then, the relative risks observed are small.

The book has accompanied me now on two holidays, which suggests that it is not a very easy read! It will not find a place on the bookshelf of most practising clinical geneticists, nor I expect a place in most departmental libraries. It should, however, be required reading for anyone considering setting up a Congenital Abnormality Register, and will be of interest to everyone engaged in research into congenital limb defects.

HELEN FIRTH 